\title{
MINERALOGICAL AND GEOCHEMICAL CHARACTERIZATION OF ROMAN SLAG FROM THE ARCHAEOLOGICAL SITE NEAR MOŠNJE (SLOVENIA)
}

\author{
MINERALOŠKA IN GEOKEMIČNA KARAKTERIZACIJA RIMSKE \\ ŽLINDRE Z ARHEOLOŠKEGA NAJDIŠČA PRI MOŠNJAH \\ (SLOVENIJA)
}

\author{
Sabina Kramar ${ }^{1}$, Judita Lux² ${ }^{2}$ Helmut Pristacz ${ }^{3}$, Breda Mirtič ${ }^{4}$, \\ Nastja Rogan - Šmuc ${ }^{4}$ \\ 1Slovenian National Building and Civil Engineering Institute, Dimičeva 12, 1000 Ljubljana, Slovenia \\ ${ }^{2}$ Institute for the Protection of Cultural Heritage of Slovenia, Preventive Archaeology Department, Tomšičeva 7, 4000 Kranj, Slovenia \\ ${ }^{3}$ University of Vienna, Institute of Mineralogy and Crystallography, Althanstrasse 14, 1090 Vienna, Austria \\ ${ }^{4}$ University of Ljubljana, Faculty of Natural Sciences and Engineering, Department of Geology, Aškerčeva 12, 1000 Ljubljana, Slovenia \\ sabina.kramar@zag.si \\ Prejem rokopisa - received: 2013-12-02; sprejem za objavo - accepted for publication: 2014-07-25
}

doi: $10.17222 /$ mit.2013.299

Roman slag from the archaeological site near Mošnje (NW Slovenia) was studied with respect to its mineralogical and geochemical characteristics. Samples were analysed with light microscopy, X-ray powder diffraction (XRD), scanning electron microscopy with an energy dispersive spectrometer (SEM-EDS) and Raman microspectroscopy. A chemical investigation was carried out using inductively coupled plasma-atomic emission spectroscopy (ICP-ES) to determine the major elements. The investigated slags are recognized as iron slags, grouped into two main classes according to their chemical and mineralogical compositions. The first group is characterized by high $\mathrm{Fe}_{2} \mathrm{O}_{3}$ and low $\mathrm{SiO}_{2}$ contents and the second by high $\mathrm{CaO}$ and $\mathrm{SiO} 2$ and low $\mathrm{Fe}_{2} \mathrm{O}_{3}$ contents. The phase occurrence obviously depends on the chemical composition as the first group mainly consists of fayalite, wüstite and magnetite, and the second one of augite, leucite, hedenbergite, monticellite and kirschsteinite.

Keywords: slag, archaeometallurgy, iron slag, Roman slag, archaeological site near Mošnje (Slovenia)

V prispevku je obravnavana rimska žlindra z arheološkega najdišča Mošnje (SZ Slovenija), pri kateri smo določili mineralno in kemijsko sestavo. Vzorci so bili analizirani s svetlobno mikroskopijo, rentgensko praškovno difrakcijo, SEM-EDS in ramansko mikrospektroskopijo. Kemijska sestava glavnih elementov je bila določena z ICP-ES. Preiskana žlindra dokazuje, da izvira iz pridelave železa na tem področju. Glede na mineraloško in kemijsko sestavo lahko delimo žlindro na dve skupini. Za prvo skupino je značilna visoka vsebnost $\mathrm{Fe}_{2} \mathrm{O}_{3}$ in nizka vsebnost $\mathrm{SiO}_{2}$, za drugo pa visoki vsebnosti $\mathrm{SiO}_{2}$ in $\mathrm{CaO}$ ter nizka vsebnost $\mathrm{Fe}_{2} \mathrm{O}_{3}$. Kemijska sestava vpliva na mineralne faze; tako je za prvo skupino značilen fajalit, wustit in magnetit, za drugo pa avgit, levcit, hedenbergit, monticelit in kirschsteinit.

Ključne besede: žlindra, arheometalurgija, železova žlindra, rimska žlindra, arheološko najdišče pri Mošnjah (Slovenija)

\section{INTRODUCTION}

The archaeological site near Mošnje with a Roman villa rustica is located in the northwestern region of Slovenia. Five masonry structures, incorporated in an embankment, were recognized. The main structure represents a residential building with seven rooms, including baths, decorated with a floor mosaic and wall paintings. The discovery of small finds such as coins, jewellery, elements of costume and fragments of pottery within closed stratigraphic layers suggests that the Roman villa rustica was inhabited during the first and second centuries $\mathrm{AD}$ and was already in ruins by the third century, whereas the archaeological finds from the mixed layers indicate that this area has been inhabited since the early Iron $\mathrm{Age}^{1}$. Excavation also provides evidence of prehistoric metallurgical activities as numerous slag occurrences - almost 400 pieces of slag - were evidenced at the mentioned location.
Slags form as by-products of metallurgical processes and they often represent the only relics of prehistoric metallurgical activities at certain archaeological sites ${ }^{2-4}$. Slags vary in terms of size, shape, and chemical and mineralogical compositions as a consequence of the technological process. In particular, the compositions and properties of metallurgical slags are influenced by the types of ores, the fluxes added, the furnace construction material (the lining), the use of charcoal and the cooling conditions ${ }^{5}$. Iron slags are routinely discovered at almost all archaeological sites throughout Slovenia ${ }^{6-9}$ and occasionally blacksmiths' hearths or smelting furnaces are also found ${ }^{10}$.

Preliminary analyses revealed that the archaeometallurgical samples from the archaeological site near Mošnje (Slovenia) differentiated in their mineralogical and chemical compositions ${ }^{11}$. Consequently, in this study, detailed mineralogical and geochemical characteristics of the slag from the Roman villa rustica were 
investigated in order to obtain information on the metallurgical operation and, thus, contribute to better knowledge and evidence of metallurgical activities.

\section{EXPERIMENTAL WORK}

\subsection{Materials}

A set of 12 archaeometallurgical samples were selected for the study. Information regarding the samples is provided in Table 1. Samples of the slag were selected from the closed stratigraphic units of the villa rustica (Figure 1). Thus, the slags from the stratigraphic units that were determined as antique (i.e., SU 280, SU 337 inside the object or SU 281) or presumably antique (SU $367)$ and the layers that periodically contained different

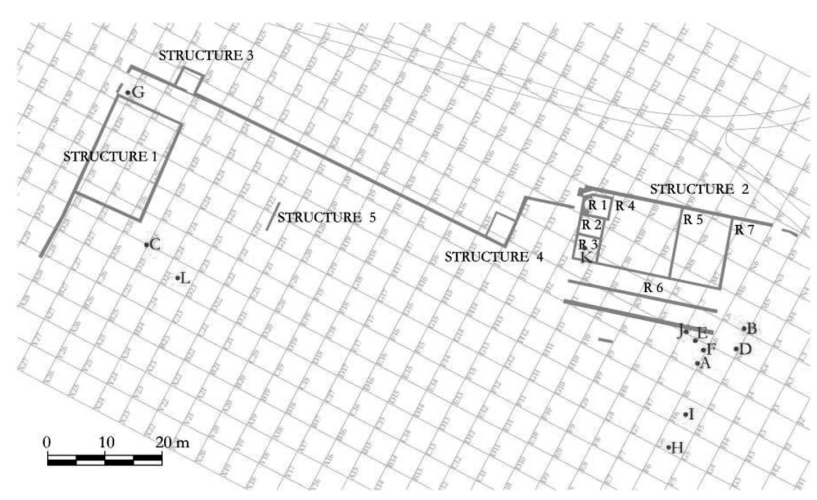

Figure 1: Plan of the villa rustica near Mošnje with marked sampling locations

Slika 1: Načrt vile rustike pri Mošnjah z označenimi vzorčnimi mesti finds (from the Roman and recent periods, i.e., SU 126, SU 38) were sampled and compared. Additionally, various layers from the inside objects, such as rubble layers (SU 337) or different coat layers (SU 280, SU 281, SU 126, 38, 367), fill layers (SU 296) and hearth remnants (SU 285) from the outside objects were selected. This selection enabled us to obtain a variety of samples that provided information regarding the diversity of the finds.

\subsection{Methods}

Polished cross-sections of the samples were studied with light microscopy using a Zeiss AX 10 equipped with an AxioCam MRc5 digital camera.

The mineral composition of the slag samples was determined with X-ray powder diffraction (XRD), using a Philips PW3710 X-ray diffractometer equipped with $\mathrm{Cu}-\mathrm{K \alpha}$ radiation and a secondary graphite monochromator. Data were collected at $40 \mathrm{kV}$ and a current of 30 $\mathrm{mA}$ in the range from $2 \theta=2^{\circ}$ to $70^{\circ}$ with a speed of 3.4 $\mathrm{r} / \mathrm{min}$. The results were analyzed with the EVA diffraction software v12 using ICSD powder diffraction files. For the purpose of the XRD analysis, the samples were milled in an agate mortar to a particle size of less than 50 $\mu \mathrm{m}$.

Polished cross-sections of the samples were examined in the back-scattered-electron (BSE) imaging mode of low-vacuum scanning electron microscopy (SEM) and the energy dispersive X-ray (EDS) technique using a JEOL $5500 \mathrm{LV}$ instrument.

Table 1: Summary of the investigated samples, their locations and mineral compositions

Tabela 1: Sinteza preiskanih vzorcev z njihovo lokacijo in mineralno sestavo

\begin{tabular}{|c|c|c|c|c|}
\hline Sample & Location & Stratigraphy & Dating & Mineral composition \\
\hline A $(6597)$ & $\mathrm{J} / 6,7$ & 280 & $\begin{array}{l}\text { Layer, Roman period; } \\
1^{\text {st }-3^{\text {rd }} \text { c. AD }}\end{array}$ & Fayalite, wüstite \\
\hline B (1499) & L6 & 126 & $\begin{array}{l}\text { Layer, mixed, } \\
\text { prehistoric-recent }\end{array}$ & Fayalite, wüstite, magnetite, quartz, goethite, $\alpha$-Fe? \\
\hline C (2630) & $\mathrm{D}, \mathrm{E} / 25,26$ & 38 & $\begin{array}{l}\text { Layer, mixed, Roman } \\
\text { period-recent }\end{array}$ & Wustite, magnetite, quartz, goethite, lepidocrocite \\
\hline D $(1580)$ & K6 & 126 & $\begin{array}{l}\text { Layer, mixed, } \\
\text { prehistoric-recent }\end{array}$ & $\begin{array}{l}\text { Fayalite, wüstite, quartz, dolomite, magnetite, } \\
\text { lepidocrocite, graphite? }\end{array}$ \\
\hline E (4193) & $\mathrm{J} 7$ & 281 & $\begin{array}{l}\text { Layer, Roman period, } \\
1^{\text {st }}, 2^{\text {nd }} c . \text { AD }\end{array}$ & Magnetite, goethite, quartz, fayalite, wüstite \\
\hline $\mathrm{F}(5006)$ & $\mathrm{J} 7$ & 281 & Layer, Roman period & $\begin{array}{l}\text { Magnetite, quartz, augite, leucite, fayalite, wüstite, } \\
\text { kirschsteinite, akermanite? }\end{array}$ \\
\hline G (5129) & $\mathrm{I} / 28,29$ & 367 & $\begin{array}{l}\text { Villa's entrance, } \\
\text { layer, Roman period? }\end{array}$ & $\begin{array}{l}\text { Quartz, augite, kirschsteinite?, fayalite, leucite, cristo- } \\
\text { balite, hercynite, monticellite, magnetite, maghaemite? }\end{array}$ \\
\hline $\mathrm{H}(3531)$ & G6 & 296 & $\begin{array}{l}\text { Fill layer, Roman } \\
\text { period }\end{array}$ & $\begin{array}{l}\text { Quartz, cristobalite, augite, leucite, hedenbergite, } \\
\text { monticellite }\end{array}$ \\
\hline I (3823) & H6 & 285 & $\begin{array}{l}\text { Hearth, Roman } \\
\text { period }\end{array}$ & Wuestite, kirschsteinite, pyrolusite, akermanite?, leucite \\
\hline J (1999) & K7 & 194 & $\begin{array}{l}\text { Layer, Roman period, } \\
1^{\text {st }-3^{\text {rd }} \text { C. AD }}\end{array}$ & Quartz, augite, anorthite, hedenbergite \\
\hline K (4100) & $\mathrm{K}, \mathrm{L} / 12$ & 0337 & $\begin{array}{l}\text { Object } 2 \text {, room } 1, \\
\text { layer, Roman period, } \\
1^{\text {st }-2^{\text {nd }} \text { c. AD }}\end{array}$ & Quartz - mullite $3: 2$, cordierite, $\alpha$-Fe?, magnetite, wüstite \\
\hline $\mathrm{L}(2641)$ & D24 & 38 & $\begin{array}{l}\text { Layer, mixed, Roman } \\
\text { period-recent }\end{array}$ & Quartz, diopside, anorthite, leucite, akermanite?, olivine \\
\hline
\end{tabular}




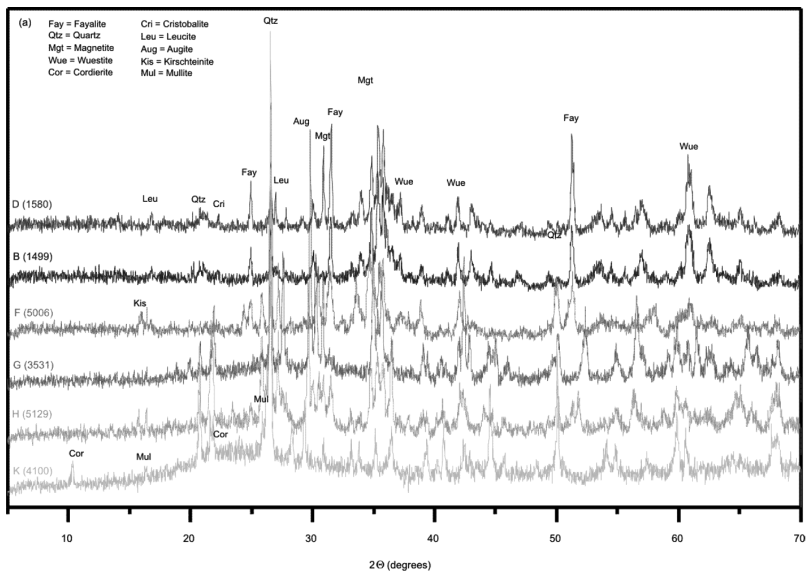

Figure 2: X-ray powder diffraction patterns of the selected samples Slika 2: Rentgenogrami izbranih vzorcev

Raman spectra of the phases were obtained on the polished cross-sections with a Horiba Jobin Yvon LabRAM HR800 Raman spectrometer equipped with an Olympus BXFM light microscope. The measurements were made using a $633 \mathrm{~nm}$ laser excitation line $(6.6 \mathrm{~mW}$ measured behind the objective) and a Leica $100^{\circ}$ objective was used. The wavenumber accuracy was better than $1 \mathrm{~cm}^{-1}$ and the spectral resolution was about $2.5 \mathrm{~cm}^{-1}$.

The samples were analysed for their major chemical components $\left(\mathrm{SiO}_{2}, \mathrm{Al}_{2} \mathrm{O}_{3}, \mathrm{Fe}_{2} \mathrm{O}_{3}, \mathrm{MgO}, \mathrm{CaO}, \mathrm{Na}_{2} \mathrm{O}\right.$, $\mathrm{K}_{2} \mathrm{O}, \mathrm{TiO}_{2}$ and $\mathrm{P}_{2} \mathrm{O}_{5}$ ) in an accredited commercial Cana- dian laboratory (Acme Analytical Laboratories, Vancouver, B.C., Canada) after fusion with a mixture of lithium metaborate/tetraborate and dissolution in nitric acid using inductively coupled plasma emission spectroscopy (ICP-ES). The accuracy and precision of the slag analysis were assessed using the reference material CCRMR SO-18 CSC. The analytical precision and accuracy were better than $\pm 5 \%$ for the investigated elements. This was indicated by the results of duplicate measurements in 12 slag samples as well as duplicate measurements of the standards.

To identify distinct groupings of the investigated samples, a hierarchical cluster analysis was applied using Ward's method and squared Euclidean distance. The basic statistical parameters for each element and the calculations mentioned above were computed using the statistical software program Statistica VII.

\section{RESULTS AND DISCUSSION}

\subsection{Mineral composition}

The mineral compositions of the samples were determined by combining various methods and they are given in Table 1. For instance, using Raman microspectroscopy, tiny crystals that could not be analysed with XRD due to their small quantity were also detected. The $\mathrm{X}$-ray powder-diffraction patterns of the selected slag samples are shown in Figure 2.
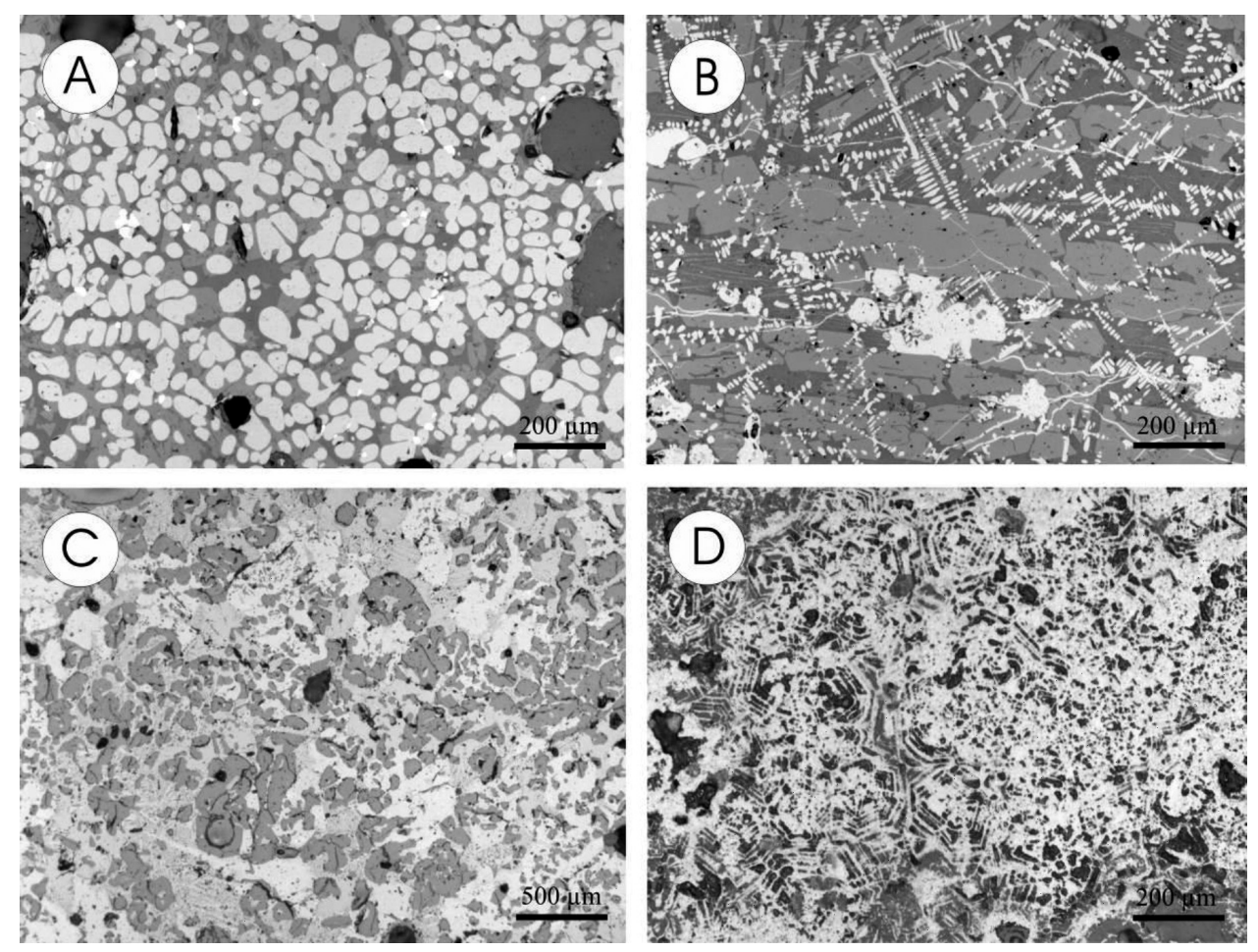

Figure 3: Microphotographs of the investigated samples: a) globular wüstite, sample A, b) dendritic wüstite and lamellar fayalite, sample D, c) abundant leucite in sample $G, d$ ) preserved carbonate structure indicating siderite ore, sample I

Slika 3: Mikroposnetki preiskanih vzorcev: a) globularni wüstit, vzorec A, b) dendritski wüstit in lamelarni fajalit, vzorec D, c) levcit, ki se pojavlja v večjih količinah, v vzorcu G, d) ohranjena karbonatna struktura, ki nakazuje sideritno rudo, vzorec I 
The investigated samples were distinguished by their mineral compositions and different distributions of the phases, most probably reflecting different stages of the iron production. The samples were recognized as the iron slags that could be grouped, in general, into two main classes according to the mineral composition.

Wüstite and fayalite are the most abundant phases in the samples of the first group (A-E). Wüstite is particularly abundant in sample A, where it occurs as globular grains (Figure 3a). Dendritic wüstite is often observed (Figure 3b). A common feature of fayalite (Figure 4a) is idiomorphic lath crystals. Besides, goethite and lepidocrocite as the weathering products or magnetite could also be detected in those samples. Quartz is present in some samples, probably from the smith's hearth, and dolomite is identified in sample D. The glassy matrix is mostly formed of $\mathrm{Si}, \mathrm{Al}$, and $\mathrm{Fe}$; small quantities of $\mathrm{K}$, $\mathrm{Na}, \mathrm{Ca}$, and $\mathrm{P}$ are also present, as determined with SEM-EDS. Samples B, C, D and E also contain the remnants of charcoal particles, which were incorporated into the slag at the smithing hearth. Larger areas of metallic iron, somewhat limonitized, are observed in samples B, C, and E, which could be part of refined bloom - gromp ${ }^{12}$.

Concerning the second group of samples $(\mathrm{F}-\mathrm{L})$, the more abundant slag phases are represented by the pyroxenes augite and hedenbergite, and $\mathrm{Ca}$-rich olivine monticellite, followed by leucite (Figures $3 \mathbf{c}$ and $\mathbf{4 b}$ ). Leucite, which is especially abundant in sample G, shows that the melt contains enhanced quantities of $\mathrm{Al}$ and $\mathrm{K}$ with respect to the melt of the samples within the first group. The samples are depleted in iron oxide, which was also noted in their microstructure, due to the absence of wüstite. While wüstite and olivine minerals predominate within the first group, in the samples of the second group they are present in small quantities or absent. Often two generations of fayalite are observed. Cordierite, mullite, cristobalite, pyrolusite and akermanite are also found, indicating furnace or smith's hearth linings. These are the minerals that were formed by firing at over $900{ }^{\circ} \mathrm{C}$ in the solid state and/or partly liquid state from the melt. However, as observed with the microscope, in those samples, slag is adhered to the ceramic (samples $\mathrm{H}, \mathrm{J}$ and $\mathrm{K}$ ). The melt of the slag is surrounded by partially reacted quartz grains; in some samples (sample $\mathrm{H}$ ) the grains of quartz sand transformed into the high-temperature-modified cristobalite during the firing, which suggests a temperature of 1200 ${ }^{\circ} \mathrm{C}$. According to the SEM-EDS analyses the glassy phase within this group contains rather smaller amounts of $\mathrm{Fe}$ (up to amount fractions $2 \%$ ) and larger amounts of $\mathrm{Mg}$ (about amount fractions $3 \%$ ) with respect to the first group. Furthermore, compared with the olivine of the first group, olivine laths contain a higher amount fractions of $\mathrm{Mg}(8 \%)$ and less Fe (16\%). Hedenbergite and monticellite also crystallized in some samples that incorporated enhanced values of $\mathrm{Ca}$ (around $6.5 \%$ ).
Ca-rich minerals, such as augite, hedenbergite and monticellite, formed due to the enhanced $\mathrm{Ca}$ content in the melt, which could have originated from several sources such as ore, ash, furnace lining or an addition of lime fluxes ${ }^{13}$. The use of sideritic ore for the iron production was proved by the preserved carbonate structures in sample I (Figure 3d). The siderite ore known from the vicinity of the archaeological site, i.e., Savske jame, Jesenice, occurring as veins between dolomite and limestone $^{14}$ could have eventually contributed to the higher lime levels. Concerning the furnace or smith's hearth linings, a lime-rich furnace lining might have resulted in the formation of lime-rich slag even if the smelted ore contained little lime ${ }^{13}$. A high quantity of pores is characteristic for the samples within the group.

\subsection{Chemical analysis}

The major elements of the 12 investigated samples along with their mean and standard deviations are presented in Table 2. The samples have heterogenic chemical compositions.

The amount fractions of $\mathrm{SiO}_{2}$ ranges from $5.79 \%$ to $65.24 \%$ in the samples. The highest $\mathrm{SiO}_{2}$ concentrations are detected in the samples of the second group $(\mathrm{F}-\mathrm{L})$.
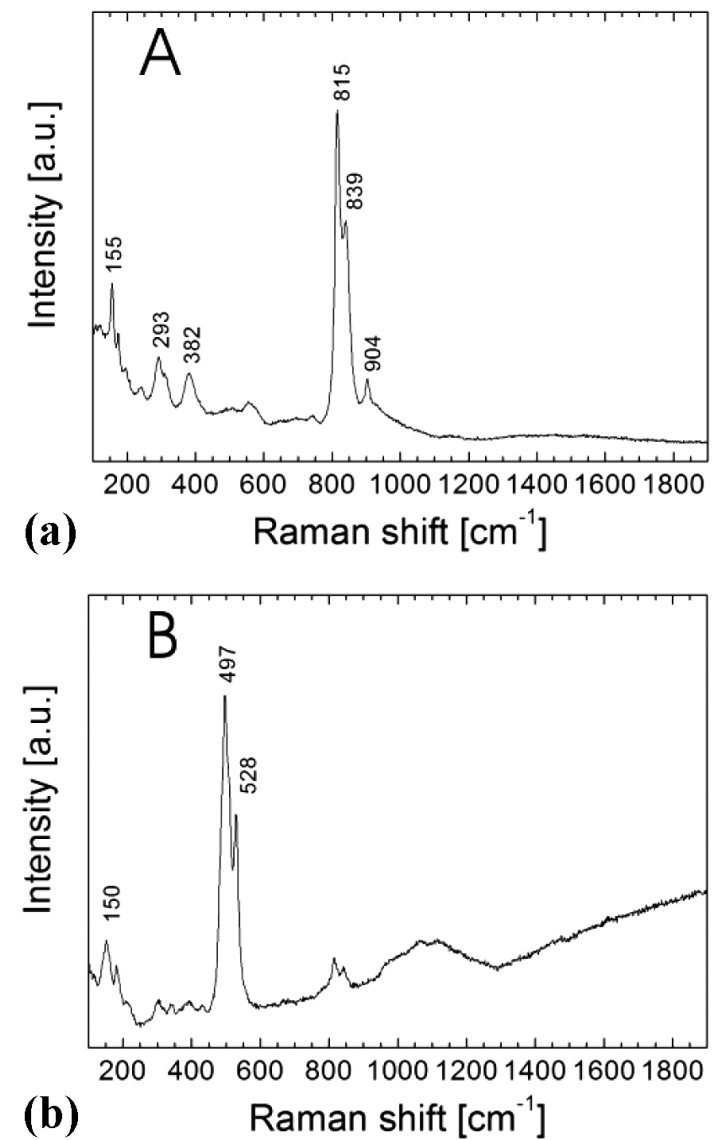

Figure 4: Raman spectra of the slag minerals of: a) fayalite (sample D) and b) leucite (sample G)

Slika 4: Ramanski spekter mineralov žlindre: a) fajalit (vzorec D) in b) levcit (vzorec G) 
Table 2: Chemical compositions (mass fractions, $w / \%$ ) of the samples

Tabela 2: Kemijska sestava (masni deleži, w/\%) vzorcev

\begin{tabular}{|c|c|c|c|c|c|c|c|c|c|c|}
\hline Sample & $\mathrm{SiO}_{2}$ & $\mathrm{Al}_{2} \mathrm{O}_{3}$ & $\mathrm{Fe}_{2} \mathrm{O}_{3}$ & $\mathrm{MgO}$ & $\mathrm{CaO}$ & $\mathrm{Na}_{2} \mathrm{O}$ & $\mathrm{K}_{2} \mathrm{O}$ & $\mathrm{TiO}_{2}$ & $\mathrm{P}_{2} \mathrm{O}_{5}$ & $\mathrm{MnO}$ \\
\hline $\mathrm{A}$ & 11.20 & 3.16 & 87.30 & 1.00 & 2.56 & 0.07 & 0.62 & 0.16 & 0.58 & 0.16 \\
\hline B & 15.43 & 3.92 & 72.77 & 0.66 & 1.44 & 0.16 & 0.68 & 0.22 & 0.42 & 0.15 \\
\hline C & 11.16 & 2.90 & 68.98 & 0.48 & 2.17 & 0.17 & 0.75 & 0.15 & 0.59 & 0.15 \\
\hline D & 17.36 & 4.40 & 70.23 & 0.83 & 1.90 & 0.18 & 0.82 & 0.25 & 0.25 & 0.18 \\
\hline E & 5.79 & 1.23 & 77.93 & 0.27 & 0.98 & 0.05 & 0.16 & 0.07 & 0.58 & 0.10 \\
\hline F & 33.11 & 7.03 & 46.68 & 2.70 & 8.85 & 0.64 & 2.60 & 0.38 & 0.47 & 0.16 \\
\hline G & 57.62 & 14.32 & 14.27 & 1.93 & 4.61 & 0.95 & 4.16 & 0.73 & 0.20 & 0.08 \\
\hline H & 52.76 & 11.91 & 10.03 & 5.13 & 11.81 & 0.61 & 2.74 & 0.56 & 0.69 & 0.15 \\
\hline I & 25.49 & 7.06 & 39.64 & 2.78 & 14.42 & 0.48 & 3.17 & 0.36 & 2.53 & 0.38 \\
\hline J & 54.77 & 14.33 & 6.18 & 6.21 & 10.76 & 0.61 & 1.82 & 0.77 & 0.54 & 0.13 \\
\hline K & 65.24 & 17.36 & 7.73 & 2.06 & 1.47 & 0.74 & 3.80 & 1.10 & 0.32 & 0.16 \\
\hline L & 56.49 & 10.87 & 17.50 & 1.54 & 6.44 & 2.48 & 1.81 & 0.46 & 1.04 & 0.16 \\
\hline Min & 5.79 & 2.90 & 6.18 & 0.27 & 1.44 & 0.07 & 0.16 & 0.07 & 0.20 & 0.08 \\
\hline Max & 65.24 & 17.36 & 87.30 & 6.21 & 11.81 & 2.48 & 4.16 & 1.10 & 2.53 & 0.38 \\
\hline Mean & 33.87 & 8.21 & 43.27 & 2.13 & 5.62 & 0.60 & 1.93 & 0.43 & 0.68 & 0.16 \\
\hline SD & 22.06 & 5.37 & 31.15 & 1.86 & 4.73 & 0.66 & 1.35 & 0.31 & 0.62 & 0.07 \\
\hline
\end{tabular}

Iron $\left(\mathrm{Fe}_{2} \mathrm{O}_{3}\right)$ and alumina $\left(\mathrm{Al}_{2} \mathrm{O}_{3}\right)$ concentrations range from $6.18 \%$ to $87.30 \%$ and from $2.90 \%$ to $17.36 \%$, respectively. The highest $\mathrm{Fe}_{2} \mathrm{O}_{3}$ concentrations are determined in samples A-E (the first group), which are mostly associated with different types of iron oxides and hydroxides (weathering) and the presence of wüstite and fayalite in these samples. According to the increased abundance of alumosilicates (augite, leucite, cordierite, mullite, and anorthite) in the studied samples, the samples of the second group contain the highest amount of $\mathrm{Al}_{2} \mathrm{O}_{3}$. Alkalis have moderate concentrations (0.05-2.48 $\%$ for $\mathrm{Na}_{2} \mathrm{O}$ and $0.16-4.016 \%$ for $\mathrm{K}_{2} \mathrm{O}$ ). The highest potassium amounts are observed in the samples of the second group, which are associated with the higher leucite amounts in the mentioned samples. In addition, the glassy matrix also hosts the elements that do not enter crystalline silicates, such as potassium originating from the charcoal ${ }^{15}$. MgO ranges between $0.27 \%$ and $6.21 \%$ (the highest values in the samples of the second group might be related to the occurrence of the $\mathrm{Mg}$-rich olivine and Mg-enriched glassy matrix), while the $\mathrm{CaO}$ content varies between $0.28 \%$ and $14.42 \%$ and is enhanced in the samples of the second group where it is sometimes incorporated in the $\mathrm{Ca}$-rich olivine and hedenbergite. Titanium $\left(\mathrm{TiO}_{2}\right)$ and phosphorous $\left(\mathrm{P}_{2} \mathrm{O}_{5}\right)$ concentrations range from $0.07 \%$ to $1.10 \%$ and from $0.20 \%$ to $2.53 \%$, without significant variations amongst the analysed samples.

The major elemental compositions generally confirm the mineral compositions of the slag samples. Additionally, the chemical compositions of the major elements were subjected to a multivariate analysis in order to distinguish individual groups among the samples studied. Figure 5 shows the results of the multivariate analysis.

Two features became evident from the evaluation of Figure 5. First, two samples, F and I, are placed as outliers within the first group. This could be because of the absence or a small quantity of the slag minerals. Second, the remaining 10 samples are clustered into two different groups according to the prevailing component: Fe-minerals or alumosilicates. The first group includes five samples (A-E) characterized by high $\mathrm{Fe}_{2} \mathrm{O}_{3}$ and low $\mathrm{SiO}_{2}$ contents. The second group comprises five samples $(\mathrm{G}$, $\mathrm{L}, \mathrm{K}, \mathrm{H}$, and $\mathrm{J}$ ) characterized by high $\mathrm{SiO}_{2}$ contents, most probably derived from quartz.

The enhanced $\mathrm{Al}_{2} \mathrm{O}_{3}$ values result in the crystallization of plagioclases and other alumosilicates. In the samples of the second group $\mathrm{Mg}$ is enhanced and it is incorporated in the glassy phase, especially in samples $\mathrm{H}$ and $\mathbf{J}$. In addition, olivine minerals are also enriched in $\mathrm{Mg}$ in these samples, as identified with SEM-EDS. The samples of the second group have enhanced values of $\mathrm{Ca}$ in the glassy phase. The enhanced $\mathrm{Ca}$ values in the samples of the second group allow the occurrence of Ca-rich olivines - kirschsteinite and monticellite - and Ca-rich pyroxene hedenbergite, and $\mathrm{Ca}$ is incorporated in the glassy phase. The Na values are enhanced in the samples of the second group and could be incorporated in the augite minerals, which was proved with the XRD analy-

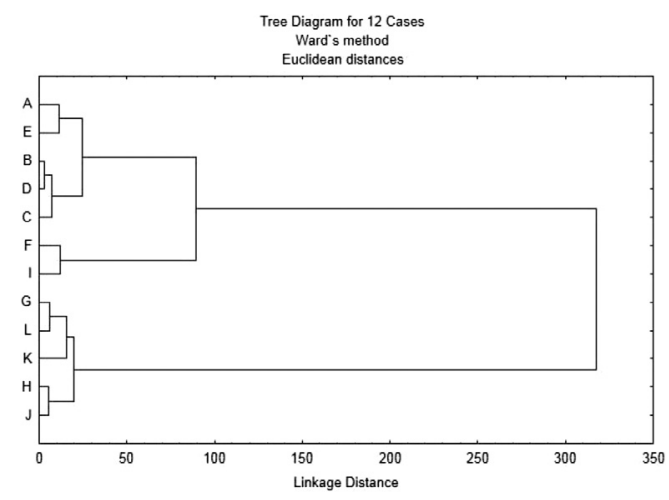

Figure 5: Investigated-sample dendrogram

Slika 5: Dendrogram preiskanih vzorcev 
sis of the samples in the second group. Potassium is sourced from the charcoal and is enhanced in the samples of the second group, where it could be incorporated in the leucite mineral and the glassy matrix. $\mathrm{K}$ and $\mathrm{Na}$ are correlated, which could indicate that $\mathrm{Na}$ and $\mathrm{K}$ were derived together from wood or charcoal.

\section{CONCLUSIONS}

The obtained results showed that the investigated samples from the archaeological site near Mošnje (Slovenia) indicate an iron production.

The samples are recognized as iron slags that can be grouped into two main slag classes according to their mineral compositions, representing different stages of the iron processes. The first group is characterized by high $\mathrm{Fe}_{2} \mathrm{O}_{3}$ and $\mathrm{CaO}$ and low $\mathrm{SiO}_{2}$ contents. The second group is characterized by high $\mathrm{SiO}_{2}$ contents. The phase occurrence obviously depends on the chemical composition as the first group consists of fayalite, wüstite and magnetite and the second of augite, hedenbergite, monticellite and kirschsteinite. The slag in some samples of the second group is adhered to the ceramic, indicating smelting or smith's hearth lining, which could have been the source of the enhanced $\mathrm{CaO}$ values of those samples. The preserved carbonate structures indicating roasted siderite ore prove the use of the local siderite ore for the iron production.

The results showed that samples A (SU 280), G (SU 367) and L (SU 38) are very particular due to their surface textures or mineral compositions. Sample $C$ from SU 38 belongs to a similar group of samples (B, D, and E), which were found in SU 126 and 281. The second group of similar samples (F, H, I, J and K) was found in Roman layers SU 194, 281, 296, 285 and 337. Thus, the groups established on the basis of the chemical-mineralogical analyses are not in complete accordance with the grouping of the samples based on their stratigraphy. For instance, among slag samples C, B, D and E, only one example (E) was found in the layer that is dated to the Roman period, while the rest are dated to a longer period - from prehistory to the modern era. However, the results indicate general varieties in the types of the slag from the archaeological site of Mošnje that can be defined in more detail only with a further study.

\section{Acknowledgements}

The above analyses were conducted as part of the post-excavation process and the study of the archaeological site of Mošnje - Pod cesto (EŠD 10036). This work was financially supported by ARRS Programme Group P2-0273 and Programme Group P1-0195.

\section{REFERENCES}

${ }^{1}$ J. Lux, M. Sagadin, Emona between Aquileia and Pannonia, Symposium in memory of Ljudmila Plesničar Gec, City Museum of Ljubljana, Slovenia, 2010, 27-28

${ }^{2}$ M. L. Wayman, Mater. Charact., 45 (2000), 259-267, doi:10.1016/ S1044-5803(00)00108-X

${ }^{3}$ R. Pleiner, Iron in Archaeology: The European Bloomery Smelters, Archaeological Institute of the Academy of Sciences, Praha 2000, 418

${ }^{4}$ R. Pleiner, Iron in Archaeology: Early European Blacksmiths, Archaeological Institute of the Academy of Sciences, Praha 2006, 379

${ }^{5}$ V. F. Buchwald, Iron and Steel in Ancient Times, Royal Danish Academy of Sciences and Letters, Copenhagen, 29 (2005), 372

${ }^{6}$ N. Zupančič, M. Mišič, RMZ - Mater. Geoenviron., 48 (2001) 3, 447-457 (in Slovene)

${ }^{7}$ L. Orengo, P. Fluzin, Iron metallurgical remnants from Trnava, Trnava, ZVKDS, Ljubljana 2006, 62-66 (in Slovene)

${ }^{8}$ J. Lamut, J. Medved, Analyses of slag, Sela pri Dobu, ZVKDS, Ljubljana 2007, 63-66 (in Slovene)

${ }^{9}$ S. Kramar, V. Tratnik, I. M. Hrovatin, A. Mladenović, H. Pristacz, N. Rogan Šmuc, Archaeometry, (2014), doi:10.1111/arcm.12116

${ }^{10}$ M. Horvat, Sela pri Dobu, ZVKDS, Ljubljana 2007, 68 (in Slovene)

${ }^{11}$ U. Umek, Mineralogical characterization of Roman slag from archaeological site Mošnje, Diplomsko delo, Ljubljana, 2011, 162 (in Slovene)

${ }^{12}$ E. M. Nosek, The metallography of gromps, La sidéurgie ancienne de 1’Est de la France dans son cintexte Européen, Ann. Litt. Univ. Besançon, 536 (1994), 65-73

${ }^{13}$ S. Paynter, Archaeometry, 48 (2006), 271-292, doi:10.1111/j.14754754.2006.00256.x

${ }^{14}$ B. Berce, Pregled železovih nahajališč LR Slovenije (Review of iron ore deposits in P. R. Slovenia), Prvi jug. Geol. Kongr., Ljubljana, 1956, 235-259 (in Slovene)

${ }^{15}$ A. Manasse, M. Mellini, J. Cult. Herit., 3 (2002), 187-198, doi:10.1016/S1296-2074(02)01176-7 